\title{
ANALISIS PENGAKUAN, PENGUKURAN, DAN PENGUNGKAPAN PENDAPATAN MENURUT SAK ETAP PADA PT. METTA KARUNA JAYA
}

\author{
Peggy Natasia Manegeng ${ }^{1}$, Jullie J.Sondakh ${ }^{2}$, Rudy J. Pusung ${ }^{3}$ \\ ${ }^{1,2,3}$ Fakultas Ekonomi dan Bisnis, Jurusan Akuntansi. Universitas Sam Ratulangi, Jl. Kampus Bahu Manado, \\ 95115, Indonesia
}

E-mail : peggymanegeng@yahoo.com

\begin{abstract}
The goal with every company is trying to gain the advantage or profit which is the maximum. Income the main of its trade comes from the sale of the goods so that the account of sales is used instead of the account of income. Problems main for income is a defining moment was this recognation of income. On the principles of recognation of income, generally income is recognized at the time be realized or can be realized and produced. Not just a matter of recognation, but also concerning the measurement and disclosure income. When entering the income in the report, the financial not correspond with the standard that applies, then there would be a mistake information for the internal and external company. This research aims at knowing of correspondence recognation, measurement, and disclosure income according to Standard Accounting Financial Entities Without Accountability Public on PT. Metta Karuna Jaya. The method of research that use is descriptive kualitatif with the use of data primary and data secondary. The result of the research show that the revenue stream PT. Metta Karuna Jaya comes from the sale of goods, the company's recognizes revenue in accordance with the SAK ETAP based on accrual basis, measuring income in accordance with the fair value that can be accepted, and disclose revenue in accordance SAK ETAP in the report profit loss company.
\end{abstract}

Keywords : revenue, recognation, measurement, disclosure, SAK ETAP

\section{PENDAHULUAN}

Tujuan utama dari setiap perusahaan adalah menghasilkan laba secara maksimal. Sumber utama pendapatan perusahaan dagang berasal dari penjualan barang dagang sehingga rekening penjualan digunakan sebagai ganti rekening pendapatan. Hery (2013), Pendapatan adalah arus masuk aktiva atau peningkatan lainnya atas aktiva atau penyelesaian kewajiban entitas (atau kombinasi keduanya) dari pengiriman barang, pemberian jasa, atau aktivitas lainnya yang merupakan operasi utama atau operasi sentral perusahaan. Pendapatan juga mengandung makna yang luas dimana dalam pendapatan termasuk pula pendapatan bunga, sewa, laba, pendapatan aktiva lain-lain. Sehingga penyajian pendapatan dalam laporan keuangan dipisahkan antara pendapatan operasional dengan pendapatan di luar pendapatan operasional.

Permasalahan yang biasanya muncul dalam pendapatan adalah pengakuan pendapatan. Perusahaan harus menentukan metode pengakuan pendapatan yang digunakan. Terdapat dua metode pengakuan pendapatan yaitu berdasarkan akrual basis dan berdasarkan kas basis. Jika perusahaan dapat menentukan metode pengakuan yang tepat maka informasi mengenai pendapatan perusahaan akan efektif dan efisien, sehingga laba yang diperoleh menjadi optimal. Tidak hanya mengenai permasalahan pengakuan saja, tetapi juga mengenai pengukuran dan pengungkapan pendapatan. Perusahaan dapat menentukan strategi usaha yang akan meningkatkan pendapatan dan laba. Pengukuran yang baik didasarkan pada nilai wajar sesuai dengan standar yang berlaku. Begitu pula masalah pengungkapan yang benar disajikan dalam laporan laba rugi perusahaan. 
Standar yang sesuai diterapkan oleh PT. Metta Karuna Jaya adalah berdasarkan SAK ETAP (Standar Akuntansi Keuangan untuk Entitas Tanpa Akuntabilitas Publik. SAK ETAP dimaksudkan untuk digunakan oleh Entitas Tanpa Akuntabilitas Publik (ETAP), yaitu entitas yang tidak memiliki akuntabilitas publik signifikan dan menerbitkan laporan keuangan untuk tujuan umum bagi pengguna eksternal. PT. Metta Karuna Jaya merupakan perusahaan yang bergerak dibidang distributor dan dikategorikan dalam perusahaan tingkat menengah atau perusahaan yang belum go public. Sehingga laporan keuangan dari PT. Metta Karuna Jaya disesuaikan dengan pencatatan pendapatan yang diatur dalam SAK ETAP. Tujuannya untuk kemudahan dalam membuat laporan keuangan, menjadikan informasi yang efektif dan efisien bagi pembuat keputusan, serta menciptakan keseragaman laporan keuangan yang wajar dan sesuai standar yang berlaku di Indonesia.

\section{TINJAUAN PUSTAKA}

\subsection{Konsep Akuntansi}

Pontoh (2013), Akuntansi adalah sebuah sistem informasi yang dirancang oleh sebuah organisasi untuk mengidentifikasi (analisis, mencatat, dan meringkas) aktivitas-aktivitas yang mempengaruhi kondisi dan kinerja keuangannya, kemudian mengkomunikasikan hasilnya kepada para pengambil keputusan, baik dari internal maupun eksternal organisasi. Akuntansi Keuangan merupakan bidang akuntansi yang menyediakan informasi akuntansi secara umum bagi para pemakai atau pengambil keputusan yang ada diluar organisasi. Informasi akuntansi keuangan dihasilkan berdasarkan Prinsip Akuntansi yang Berlaku Umum (PABU) atau Generally Accepted Accounting Principles (GAAP).

Kebanyakan sistem akuntansi dirancang untuk menghasilkan informasi, baik untuk pelaporan internal maupun eksternal. Perusahaan pertama kali harus dapat mengidentifikasi dengan baik, langkah selanjutnya adalah mulai merancang sistem akuntansi. Akhirnya, sistem akuntansi tadi akan mencatat seluruh data yang menyangkut aktivitas perusahaan. Setelah transaksi dicatat dan diikhtisarkan, laporan dapat disiapkan untuk kepentingan users. Laporan akuntansi yang memberikan informasi ini dinamakan laporan keuangan (financial ststements).

\subsection{Tujuan Pelaporan Keuangan}

Tujuan keseluruhan dari pelaporan keuangan adalah untuk memberikan informasi yang berguna bagi investor dan kreditur dalam pengambilan keputusan investasi dan kredit. Jenis keputusan yang dibuat oleh pengambil keputusan sangatlah beragam, begitu juga dengan metode pengambilan keputusan yang mereka gunakan dan kemampuan mereka untuk memproses informasi.

Pengguna informasi akuntansi harus dapat memperoleh pemahaman mengenai kondisi keuangan dan hasil operasional perusahaan lewat pelaporan keuangan. Investor sangat berkepentingan terhadap laporan keuangan yang disusun investee terutama dalam hal pembagian dividen, sedangkan kreditur berkepentingan dalam hal pengembalian jumlah pokok pinjaman berikut bunganya. Investor dan kreditur terutama sangat tertarik terhadap arus kas investee/debitur di masa mendatang.

\subsection{Unsur- Unsur Laporan Keuangan}

Berikut adalah definisi dari masing-masing kesepuluh unsur laporan keuangan (Hery, 2013):

1. Aktiva adalah manfaat ekonomi yang mungkin terjadi di masa depan, yang diperoleh atau dikendalikan oleh entitas sebagai hasil dari transaksi atau peristiwa di masa lalu.

2. Kewajiban adalah pengorbanan atas manfaat ekonomi yang mungkin terjadi di masa depan, yang timbul dari kewajiban entitas pada saat ini.

3. Ekuitas adalah kepemilikan atau kepentingan residu dalam aktivitas entitas, yang masih tersisa setelah dikurangi dengan kewajibannya. 
4. Investasi oleh pemilik adalah kenaikan ekuitas (aktiva bersih) entitas yang dihasilkan dari penyerahan sesuatu yang bernilai oleh entitas lain untuk memperoleh atau meningkatkan bagian kepemilikannya.

5. Distribusi kepada pemilik adalah penurunan ekuitas (aktiva bersih) entitas yang disebabkan oleh penyerahan aktiva, jasa, atau terjadinya kewajiban entitas kepada pemilik.

6. Laba komprehensif adalah perubahan dalam ekuitas entitas sepanjang suatu periode sebagai akibat dari transaksi dan peristiwa serta keadaan-keadaan lainnya bukan bersumber dari pemilik.

7. Pendapatan adalah arus masuk aktiva atau peningkatan lainnya atas aktiva atau penyelesaian kewajiban entitas (atau kombinasi dari keduanya) dari pengiriman barang, pemberian jasa, atau aktivitas lainnya.

8. Beban adalah arus keluar aktiva atau penggunaan lainnya atas aktiva atau terjadinya (munculnya) kewajiban entitas (atau kombinasi keduanya) yang disebabkan oleh pengiriman atau pembuatan barang, pemberian jasa, atau aktivitas lainnya.

9. Keuntungan adalah kenaikan dalam ekuitas (aktiva bersih) yang ditimbulkan oleh transaksi peripheral (transaksi diluar operasi utama perusahaan) atau transaksi insidentil (transaksi yang keterjadiaanya jarang) dan dari seluruh transaksi lainnya serta peristiwa maupun keadaan-keadaan lainnya yang mempengaruhi entitas.

10. Kerugian adalah penurunan dalam ekuitas (aktiva bersih) entitas yang ditimbulkan oleh transaksi peripheral atau transaksi insidentil dan dari selutuh transaksi lainnya serta peristiwa maupun keadaan-keadaan lainnya yang mempengaruhi entitas.

\subsection{Pendapatan Menurut SAK ETAP}

IAI (2013), Dalam akuntansi untuk pendapatan yang muncul sebagai akibat dari transaksi atau kejadian berikut:

a) Penjualan barang (baik produksi oleh entitas untuk tujuan produksi atau dibeli untuk dijual kembali)

b) Pemberian jasa

c) Kontrak konstruksi

d) Penggunaan aset entitas oleh pihak lain yang menghasilkan bunga, royalti, atau dividen.

Pendapatan atau penghasilan lain yang muncul dari beberapa transaksi dan kejadian lain berikut ini:

a) perjanjian sewa;

b) dividen yang timbul dari investasi yang dihitung dengan menggunakan metode ekuitas; perubahan nilai wajar investasi pada efek tertentu, atau pelepasannya.

\subsection{Pengukuran Pendapatan}

Pengukuran adalah proses penetapan jumlah uang yang digunakan entitas untuk mengukur aset, kewajiban, penghasilan dan beban dalam laporan keuangan. Dasar pengukuran pendapatan yang diterapkan dalam laporan keuangan adalah berdasarkan nilai wajar atas pembayaran yang diterima atau masih harus diterima (SAK ETAP, 2013, p.2.30). Entitas harus mengukur pendapatan berdasarkan nilai wajar atas pembayaran yang diterima atau masih harus diterima. Nilai wajar tersebut tidak termasuk jumlah diskon penjualan dan potongan volume.

\subsection{Pengungkapan Pendapatan}

Menurut SAK ETAP (2013, p.20.28), Pengungkapan adalah sebuah proses akuntansi dimana entitas menunjukkan atau mengungkapkan :

a) kebijakan akuntansi yang diterapkan sebagai dasar pengakuan pendapatan, termasuk metode yang diterapkan untuk menentukan tingkat penyelesaian transaksi yang melibatkan penyediaan jasa; 
b) jumlah setiap kategori pendapatan yang diakui selama periode, termasuk pendapatan yang timbul dari:
i) penjualan barang;
ii) penyediaan jasa;
iii) bunga;
iv) royalti;
v) dividen;
vi) jenis pendapatan signifikan lainnya.

\subsection{Penelitian Terdahulu}

1. Synthia Marcella / 2014 berjudul Analisis Pengakuan dan Pengukuran Pendapatan Berdasarkan PSAK No. 23 pada PT. Pandu Siwi Sentosa Palembang. Metode yang digunakan Kualitatif. Hasil penelitian menunjukan pengakuan pendapatan pada PT. Pandu Siwi Sentosa Palembang menyimpang dari PSAK No. 23 yang mana pada akhir tahun dalam laporan keuangan PT. Pandu Siwi Sentosa Palembang tidak mencatat pendapatan dari pelanggan yang sesungguhnya.

2. Kadek Arsani / 2013 Perlakuan Akuntansi Pendapatan dan Beban Berbasis SAK ETAP dan Implikasinya pada Laporan Keuangan KSP Duta Sejahtera. Metode yang digunakan Kualitatif. Hasil penelitian menunjukan perlakuan akuntansi pendapatan dan beban yang diterapkan KSP Duta Sejahtera belum sesuai dengan SAK ETAP.

3. Elisabeth Pawan / 2013 berjudul Pengakuan, Pengukuran, Pengungkapan, dan Pelaporan Pendapatan berdasarkan PSAK No. 23 pada PT. Pegadaian (PERSERO). Metode yang digunakan Deskriptif. Hasil penelitian menunukkan pengakuan pendapatan pada PT. Pegadaian (Persero) dilakukan dengan menggunakan akrual basis sesuai dengan PSAK No. 23.

\section{METODE PENELITIAN}

\subsection{Jenis dan sumber data}

Jenis penelitian yang digunakan penulis adalah penelitian kualitatif. Sugiyono (2014) menyatakan bahwa Metode Penelitian Kualitatif adalah metode penelitian yang berlandaskan pada filsafat Postpositivisme, digunakan untuk meneliti pada kondisi objek yang alamiah, dimana peneliti adalah sebagai instrument kunci, pengambilan sampel sumber data dilakukan secara purposive dan snowball, teknik pengumpulan data dilakukan secara triangulasi (gabungan), analisis data bersifat induktif, dan penelitian lebih menekan makna generalisasi.

Berdasarkan sumbernya, data dibagi menjadi:

a. Data Primer adalah data yang diperoleh dari responden melalui kuesioner, kelompok fokus, dan panel, atau juga data hasil wawancara peneliti dengan narasumber.

b. Data Sekunder adalah data yang didapat dari catatan, buku, majalah berupa laporan keuangan publikasi perusahaan, laporan pemerintah, artikel, buku-buku sebagai teori, majalah, dan lain sebagainya (Sujaweni, 2014).

Dalam penelitian ini, sumber data yang digunakan adalah sumber data primer dan sumber data sekunder. Sumber data primer berupa sejarah perusahaan, dan kegiatan operasional perusahaan. Sedangkan untuk data sekunder berupa laporan laba rugi PT. Metta Karuna Jaya, struktur oraganisasi, dan contoh faktur perusahaan.

\subsection{Teknik pengambilan sampel}

Dalam penelitian ini teknik pengumpulan data yang digunakan adalah:

1. Teknik Wawancara yaitu teknik pengumpulan data, apabila peneliti ingin melakukan studi pendahuluan untuk mengemukakan permasalahan yang harus diteliti, dan juga apabila peneliti ingin mengetahui hal-hal dari responden yang lebih mendalam dan jumlah respondennya sedikit/kecil. Dalam penelitian ini wawancara yang dilakukan 
yaitu diskusi langsung, dan tanya jawab dengan pihak-pihak terkait pada PT. Metta Karuna Jaya.

2. Teknik Dokumentasi yaitu melakukan pengumpulan data dari PT. Metta Karuna Jaya seperti laporan laba rugi, dan data lainnya yang terkait dengan penelitian.

\subsection{Metode analisis}

Metode analisis yang digunakan adalah metode deskriptif kualitatif. Metode analisis data yang dilakukan meliputi :

1. Melakukan pengumpulan data pada PT. Metta Karuna Jaya.

2. Menganalisa data dan melakukan perbandingan pengakuan pendapatan perusahaan terhadap SAK ETAP.

3. Menganalisa data dan melakukan perbandingan pengukuran pendapatan perusahaan terhadapap SAK ETAP.

4. Menganalisa dan melakukan perbandingan pengungkapan pendapatan perusahaan terhadap SAK ETAP.

5. Menarik kesimpulan dan memberikan saran bagi perkembangan dan kemajuan perusahaan.pulan dan memberikan saran bagi perkembangan dan kemajuan perusahaan.

\section{HASIL ANALISIS DAN PEMBAHASAN}

\subsection{Hasil analisis}

Pendapatan operasional yang diperoleh PT. Metta Karuna Jaya adalah penjualan barang dagangan. Sedangkan pendapatan non operasional yang diperoleh dari pendapatan klaim. Sebagai perusahaan distibutor, PT. Metta Karuna Jaya menjual kembali barang dagangan dari PT. Frisian Flag Indonesia. Produk-produk yang dijual kembali, seperti : Omela, Yes Fruity, Frisolac, Frisian Flag, Energo, Susu Bendera, Yes Mut-Mut, Friso Mum, dan Friso. Kemudian produk-produk tersebut dijual kembali ke pegecer agar dapat menjangkau konsumen.

Penjualan PT. Metta Karuna Jaya tidak hanya penjualan tunai adapun penjualan kredit. Sebagian besar pendapatan yang dihasilkan PT. Metta Karuna Jaya merupakan penjualan kredit 98\% dari penjualan bruto. Pada tahun 2011 penjualan kredit sebesar Rp. 20.089.679.890, di tahun 2012 sebesar Rp. 41.519.123.180, dan di tahun 2013 sebesar Rp. 50.344.419.170. Sedangkan untuk penjualan tunai dilakukan untuk penjualan ukuran kecil.

Penjualan bruto PT. Metta Karuna Jaya menunjukkan peningkatan setiap tahunnya. Pada tahun 2011 penjualan bruto sebesar Rp. 20.499.673.356, tahun 2012 sebesar Rp. 42.366.452.228, dan di tahun 2013 sebesar Rp. 51.371.856.301. Antara tahun 2011 dengan tahun 2012 penjualan bruto meningkat sebesar 2,07\%, untuk tahun 2012 dengan tahun 2013 penjualan bruto meningkat sebesar $1,21 \%$. Berikut merupakan laporan laba rugi tahun 20112013 PT. Metta Karuna Jaya.Times New Roman 12, spasi tunggal 0 pt, penyesuaian pada batas kiri dan kanan. 


\section{Tabel 4.1. Laporan Laba Rugi \\ PT. Metta Karuna Jaya \\ Laporan Laba Rugi}

\begin{tabular}{|c|c|c|c|c|}
\hline No. & Nama Rekening & $\begin{array}{c}\text { Per } 31 \text { Desember } \\
2011 \\
\end{array}$ & $\begin{array}{c}\text { Per } 31 \text { Desember } \\
2012 \\
\end{array}$ & $\begin{array}{c}\text { Per } 31 \text { Desember } \\
2013 \\
\end{array}$ \\
\hline A. & PENJUALAN & & & \\
\hline A. 1 & Penjualan & $20,499,673,356$ & $42,366,452,228$ & $51,371,856,301$ \\
\hline A.2 & Diskon Penjualan & $(507,124,534)$ & $(1,023,450,756)$ & $(1,277,534,165)$ \\
\hline A.3 & Retur Penjualan & $(34,941,464)$ & $(59,414,645)$ & $(74,454,245)$ \\
\hline A.4 & Penjualan Netto & $19,957,607,357$ & $41,283,586,827$ & $50,019,867,891$ \\
\hline B. & $\begin{array}{l}\text { HARGA POKOK } \\
\text { PENJUALAN }\end{array}$ & & & \\
\hline B. 1 & $\begin{array}{l}\text { Persediaan Awal } \\
\text { Barang Dagangan }\end{array}$ & - & $2,803,768,000$ & $2,503,768,000$ \\
\hline B.2 & Pembelian & $21,505,079,000$ & $37,881,680,000$ & $47,281,680,000$ \\
\hline B.3 & Diskon Pembelian & $(860,203,160)$ & $(1,136,450,400)$ & $(1,418,450,400)$ \\
\hline B.4 & Retur Pembelian & - & - & - \\
\hline B. 5 & $\begin{array}{l}\text { Biaya Angkut } \\
\text { Pembelian }\end{array}$ & $132,585,880$ & $227,290,080$ & $425,535,120$ \\
\hline B.6 & $\begin{array}{l}\text { Jumlah Barang } \\
\text { Tersedia Untuk } \\
\text { Dijual }\end{array}$ & $20,777,461,720$ & $39,776,287,680$ & $48,792,532,720$ \\
\hline B.7 & $\begin{array}{l}\text { Persediaan Akhir } \\
\text { Barang Dagangan }\end{array}$ & $(2,803,768,000)$ & $(2,503,768,000)$ & $(3,503,768,000)$ \\
\hline B. 8 & $\begin{array}{l}\text { HARGA POKOK } \\
\text { PENJUALAN }\end{array}$ & $17,973,693,720$ & $37,272,519,680$ & $45,288,764,720$ \\
\hline C. & LABA BRUTO & 1,983,913,637 & $4,011,067,147$ & 4,731,103,171 \\
\hline D. & $\begin{array}{l}\text { BIAYA } \\
\text { OPERASIONAL }\end{array}$ & & & \\
\hline D.1 & $\begin{array}{l}\text { BIAYA } \\
\text { PENJUALAN / } \\
\text { PEMASARAN : }\end{array}$ & & & \\
\hline D.1.1 & Biaya Bahan Bakar & $99,008,000$ & $232,128,000$ & $253,968,000$ \\
\hline & $\begin{array}{l}\text { Biaya Reparasi \& } \\
\text { Pemeliharaan } \\
\text { Kendaraan } \\
\end{array}$ & $7,104,000$ & $18,534,250$ & $22,229,350$ \\
\hline D.1.2 & $\begin{array}{l}\text { Biaya Parkir } \\
\text { Kendaraan }\end{array}$ & $8,190,000$ & $17,160,000$ & $20,280,000$ \\
\hline D.1.3 & Biaya Barang Cetakan & $19,750,600$ & $22,682,350$ & $27,345,100$ \\
\hline D.1.4 & Biaya Sewa Gudang & 105,000 & $180,000,000$ & $180,000,000$ \\
\hline D.1.5 & $\begin{array}{l}\text { Biaya Insentif } \\
\text { Penjualan }\end{array}$ & $70,200,000$ & $135,325,600$ & $161,345,600$ \\
\hline D.1.6 & $\begin{array}{l}\text { Biaya Kerugian } \\
\text { Piutang }\end{array}$ & $43,891,456$ & $68,673,451$ & $51,532,573$ \\
\hline D.1.7 & $\begin{array}{l}\text { Jumlah Biaya } \\
\text { Penjualan / Pemasaran }\end{array}$ & $353,144,056$ & $674,503,651$ & $716,700,623$ \\
\hline No. & Nama Rekening & $\begin{array}{c}\text { Per } 31 \text { Desember } \\
2011 \\
\end{array}$ & $\begin{array}{c}\text { Per } 31 \text { Desember } \\
2012 \\
\end{array}$ & $\begin{array}{c}\text { Per } 31 \text { Desember } \\
2013 \\
\end{array}$ \\
\hline D.2 & $\begin{array}{l}\text { BIAYA ADM. DAN } \\
\text { UMUM }\end{array}$ & & & \\
\hline D.2.1 & Biaya Gaji Pegawai & $359,297,400$ & $615,938,400$ & $700,678,000$ \\
\hline D.2.2. & $\begin{array}{l}\text { Biaya Foto Copy \& } \\
\text { ATK Kantor }\end{array}$ & $1,250,300$ & $1,500,400$ & $2,500,300$ \\
\hline D.2.3 & Biaya Listrik & $13,976,424$ & $23,234,100$ & $25,671,100$ \\
\hline
\end{tabular}




\begin{tabular}{|c|c|c|c|c|}
\hline No. & Nama Rekening & $\begin{array}{c}\text { Per } 31 \text { Desember } \\
2011\end{array}$ & $\begin{array}{c}\text { Per 31 Desember } \\
2012\end{array}$ & $\begin{array}{c}\text { Per } 31 \text { Desember } \\
2013\end{array}$ \\
\hline D.2.4 & Biaya Telepon & $14,041,072$ & $27,849,000$ & $29,324,500$ \\
\hline D. 2.5 & $\begin{array}{l}\text { Biaya PAM \& Air } \\
\text { Galon }\end{array}$ & $4,430,280$ & $5,316,000$ & $6,479,000$ \\
\hline D.2.6 & Biaya Pengiriman & 660,000 & 792,000 & 950,400 \\
\hline D.2.7 & $\begin{array}{l}\text { Biaya Reparasi \& } \\
\text { Pemeliharaan Kantor }\end{array}$ & $2,575,000$ & $3,090,000$ & $3,708,500$ \\
\hline D.2.8 & $\begin{array}{l}\text { Biaya Transportasi \& } \\
\text { BBM }\end{array}$ & $12,796,000$ & $19,350,000$ & $23,100,000$ \\
\hline D.2.9 & Biaya Asuransi & $3,500,000$ & $4,200,000$ & $5,600,000$ \\
\hline D.2.10 & $\begin{array}{l}\text { Biaya Sewa Gedung } \\
\text { Kantor }\end{array}$ & $70,000,000$ & $120,000,000$ & $120,000,000$ \\
\hline D.2.11 & $\begin{array}{l}\text { Biaya Iuran dan } \\
\text { Retribusi }\end{array}$ & $1,300,300$ & $1,750,200$ & $2,151,200$ \\
\hline D.2.12 & Biaya Bunga Pinjaman & $45,734,568$ & $67,523,567$ & $31,235,651$ \\
\hline D.2.13 & $\begin{array}{l}\text { Biaya Keperluan } \\
\text { Dapur }\end{array}$ & $52,325,000$ & $81,790,000$ & $50,435,000$ \\
\hline D.2.14 & $\begin{array}{l}\text { Biaya Perjalanan } \\
\text { Dinas }\end{array}$ & $19,375,500$ & $23,345,000$ & $28,450,750$ \\
\hline D.2.15 & $\begin{array}{l}\text { Biaya Sumbangan \& } \\
\text { Entertainment }\end{array}$ & $8,567,750$ & $10,254,570$ & $25,354,500$ \\
\hline D.2.16 & $\begin{array}{l}\text { Biaya Penyusutan } \\
\text { Kendaraan }\end{array}$ & $96,147,322$ & $164,823,981$ & $164,823,981$ \\
\hline D.2.17 & $\begin{array}{l}\text { Biaya Penyusutan } \\
\text { Inventaris Kantor }\end{array}$ & $15,098,854$ & $25,883,750$ & $25,883,750$ \\
\hline \multirow[t]{3}{*}{ D.2.18 } & $\begin{array}{l}\text { Biaya Adm. \& Umum } \\
\text { Lainnya }\end{array}$ & $8,325,000$ & $1,450,560$ & $6,345,100$ \\
\hline & $\begin{array}{l}\text { Jumlah Biaya Adm. } \\
\text { \& Umum }\end{array}$ & $729,400,771$ & $1,198,091,528$ & $1,252,591,732$ \\
\hline & $\begin{array}{l}\text { TOTAL BIAYA } \\
\text { OPERASIONAL }\end{array}$ & $1,082,544,827$ & $1,872,595,179$ & $1,969,292,355$ \\
\hline E. & $\begin{array}{l}\text { LABA BRUTO } \\
\text { OPERASIONAL }\end{array}$ & $901,368,811$ & $2,138,471,968$ & $2,761,810,815$ \\
\hline
\end{tabular}

\section{Sumber : Laporan Tahunan PT. Metta Karuna Jaya}

\section{Pengakuan Pendapatan PT. Metta Karuna Jaya}

Perusahaan mengakui pendapatannya saat transaksi dilakukan walaupun kas belum diterima. Penjualan barang yang dilakukan PT. Metta Karuna Jaya mengakui pendapatannya saat terjadi transaksi dan disesuaikan dengan periode tahun berjalan. Konsep akrual basis digunakan perusahaan untuk menunjukkan pendapatan yang seharusnya diterima oleh perusahaan.

Saat terjadi penjualan kredit piutang perusahaan tentunya akan bertambah dan sebaliknya jika konsumen melunasi kredit berarti piutang akan berkurang sehingga kas akan diterima. Perusahaan harus dapat mengestimasi transaksi dengan andal dan memperoleh kembali biaya yang terpakai. Sehingga kemungkinan manfaat ekonomi akan mengalir ke perusahaan serta dapat diukur dengan andal.

Pengakuan pendapatan PT. Metta Karuna Jaya disesuaikan dengan pencatatan perusahaan dagang secara umum. Pencatatan yang dilakukan perusahaan disesuaikan dengan metode akrual basis atau pencatatan transaksi baik yang bersifat tunai maupun kredit.

Saat transaksi tunai terjadi walaupun kas belum diterima perusahaan akan mencatat sebagai berikut: 


Tanggal Kas $\quad$ Pxx

Sedangkan untuk mencatat transaksi penjualan secara kredit adalah sebagai berikut:

Tanggal Piutang usaha xxx Penjualan $\quad \mathrm{xxx}$

Untuk retur penjualan, perusahaan akan mencatat sebagai berikut:

Tanggal Retur penjualan xxx Piutang usaha $\quad \mathrm{xxx}$

Untuk mencatat pengembalian persediaan sebagai berikut:

Tanggal Persediaan barang dagang $\mathrm{xxx}$ Harga pokok penjualan $\quad \mathrm{xxx}$

\section{Pengukuran Pendapatan PT. Metta Karuna Jaya}

Dasar pengukuran yang digunakan terhadap pendapatan PT. Metta Karuna Jaya berdasarkan nilai wajar. Pengukuran pendapatan diukur berdasarkan nilai wajar atas pembayaran yang telah diterima atau masih harus diterima. PT. Metta Karuna Jaya mengukur pendapatan yang diperoleh berdasarkan jumlah uang yang dibayarkan pelanggan dan tarif dasar yang ditetapkan berdasarkan biaya yang dikeluarkan untuk mendistribusikan produk pada pelanggan. Pengukuran pendapatan mengacu pada nilai sekarang dari uang atau ekuivalen uang yang akhirnya akan diterima sebagai hasil proses produksi atau transaksi pendapatan.

Pendapatan PT. Metta Karuna Jaya diukur berdasarkan jumlah penghasilan atas penjualan produk dan penghasilan lainnya. Pengukuran pendapatan secara akrual basis dicatat dengan jurnal sebagai berikut:

$$
\begin{array}{ccc}
\text { Tanggal } & \text { Piutang usaha } & \text { xxx } \\
& \text { Pendapatan } & \text { xxx }
\end{array}
$$

\section{Pengungkapan Pendapatan PT. Metta Karuna Jaya}

Dalam hal pengungkapan, PT. Metta Karuna Jaya mengungkapkan dan menyajikan elemen penghasilan dan elemen beban dalam laporan laba rugi perusahaan. Penghasilan PT. Metta Karuna Jaya dalam laporan laba rugi tahun 2013 adalah sebesar Rp. 51.371.856,301 sesuai dengan penjualan perusahaan.

Kebijakan akuntansi yang diterapkan oleh perusahaan menggunakan metode akrual basis. Perusahaan mengakui metode akrual basis dengan alasan untuk menentukan tingkat penyelesaian transaksi penjualan.

\subsection{Pembahasan}

\section{Analisis Pengakuan Pendapatan PT. Metta Karuna Jaya}

Berdasarkan data penelitian dalam jurnal penerimaan kas PT. Metta Karuna Jaya mengakui pendapatan dengan menginput pesanan saat terjadi penerimaan kas dari pelanggan atas pelunasan tagihan atau faktur. Hal ini menunjukkan bahwa perusahaan mengakui pendapatannya secara akrual basis sesuai dengan SAK ETAP.

Proses terjadinya penjualan pada PT. Metta Karuna Jaya diawali dengan pemesan produk lewat bagian sales dan diinput lewat gadget. Jika transaksi dalam bentuk tunai akan diinput sebagai penjualan kas sebaliknya jika transaksi bersifat kredit akan diinput sebagai penjualan kredit. Adapun retur penjualan atau kemungkinan produk dikembalikan oleh pelanggan karena adanya kerusakan produk baik dari pabrik maupun saat pengiriman ke pelanggan.

Setiap transaksi pada penjualan kredit, konsumen akan diberikan faktur oleh perusahaan. Jika pada penjualan tunai konsumen akan diberikan bukti pelunasan dari perusahaan. Faktur tersebut terdapat dua salinan yang dipegang oleh konsumen dan perusahaan. Dalam faktur pun perusahaan menetapkan tanggal jatuh tempoh pelunasan 
barang secara kredit. Jika terjadi pelunasan maka faktur yang dipegang akan ditandai oleh agen dari perusahaan. Karena PT. Metta Karuna Jaya menggunakan sistem komputer dalam pencatatan transaksi kredit maupun tunai. Bagian sales melakukan transaksi langsung menggunakan tablet (gadget), jadi pencatatan transaksi langsung terinput dalam sistem komputer. Sehingga memudahkan proses transaksi, dimana konsumen tidak harus ke perusahaan. Transaksi penjualan yang dilakukan melibatkan penambahan aktiva ke dalam perusahaan, yang berupa kas jika pembayarannya secara tunai sedangkan pembayaran secara kredit berupa piutang dagang. Perusahaan juga melakukan pencatatan manual walaupun data transaksi telah terinput dalam sistem komputerisasi. Hal ini bertujuan untuk mencadangkan data jika sewaktu-waktu sistem komputer bermasalah dengan data yang ada.

Pengakuan pendapatan PT. Metta Karuna Jaya telah disesuaikan dengan SAK ETAP bab 20, adalah sebagai berikut:

1. Entitas telah mengalihkan risiko dan manfaat yang signifikan dan kepemilikan barang kepada pembeli

2. Entitas tidak mempertahankan atau meneruskan baik keterlibatan manajerial sampai kepada tingkat di mana biasanya diasosiasikan dengan kepemilikan maupun kontrol efektif atas barang yang terjual

3. Jumlah pendapatan dapat diukur secara andal

4. Ada kemungkinan besar manfaat ekonomi yang berhubungan dengan transaksi akan mengalir masuk ke dalam entitas

5. Biaya yang telah atau akan terjadi sehubungan dengan transaksi dapat diukur secara andal.

\section{Analisis Pengukuran Pendapatan PT. Metta Karuna Jaya}

Data penelitian perusahaan menunjukkan bahwa PT. Metta Karuna Jaya telah mengukur jumlah pendapatan sesuai dengan SAK ETAP karena menggunakan salah satu dasar pengukuran yaitu nilai wajar. Di mana PT. Metta Karuna Jaya dalam mengukur pendapatan sesuai jumlah yang dipakai untuk menukarkan aset (produk).

Pengukuran dilakukan dengan nilai tukar jumlah uang disepakati harus dibayarkan oleh konsumen pada saat terjadinya transaksi. Nilai tukar menunjukan ekuivalen kas atau nilai sekarang dari tagihan-tagihan yang diharapkan akan diterima dari transaksi pendapatan, nilai ini bisa di ekuivalen dengan harga yang disepakati dalam transaksi dengan pelanggan. Pendapatan yang diterima dicatat sebesar penerimaan kas yang diterima atau sebesar nilai wajar imbalan yang diberikan untuk memperoleh pendapatan tersebut.

Pendapatan perusahaan diukur berdasarkan setoran kas (faktur) pelanggan. Hal ini menunjukkan bahwa faktur memiliki peranan penting dalam pengukuran pendapatan. Faktur dibuat oleh perusahaan bagi pelanggan untuk mengetahui jumlah kewajiban atas penjualan produk yang harus dibayarkan pada PT. Metta Karuna Jaya. Faktur yang dibuat oleh perusahaan tertera tanggal jatuh tempo pelunasan barang secara kredit yang ditentukan oleh PT. Metta Karuna Jaya.

PT. Metta Karuna Jaya juga melakukan pengukuran pada laporan keuangannya dalam laporan laba rugi perusahaan. Laporan laba rugi perusahaan menunjukkan pendapatan yang dihasilkan adalah pendapatan bruto. Hal tersebut juga telah sesuai dengan SAK ETAP bahwa entitas harus memasukkan dalam pendapatan manfaat ekonomi yang diterima atau masih harus diterima secara bruto.

\section{Analisis Pengungkapan Pendapatan PT. Metta Karuna Jaya}

PT. Metta Karuna Jaya membedakan pendapatan usaha menjadi penjualan produk dalam laporan laba rugi perusahaan. Pendapatan yang dihasilkan dari penjualan merupakan hasil penjualan produk-produk PT. Frisian Flag Indonesia. Sumber pendapatan PT. Metta Karuna Jaya diungkapkan dan disajikan menurut posnya masing-masing. Demikian pula dengan laporan keuangan PT. Metta Karuna Jaya diungkapkan atas dasar akrual basis. 
Perusahaan mengakui metode akrual basis dengan alasan untuk menentukan tingkat penyelesaian transaksi penjualan. Hal tersebut ternyata telah sesuai dengan SAK ETAP yang berlaku. Berdasarkan pengungkapan pendapatan PT. Metta Karuna Jaya dalam laporan laba rugi, pengungkapan sudah sesuai dengan SAK ETAP bahwa jumlah setiap kategori pendapatan yang diakui selama periode, termasuk pendapatan yang timbul dari penjualan barang.

\section{Tabel 4.2 Perbandingan Kriteria Pengakuan Pendapatan Menurut SAK ETAP dengan} PT. Metta Karuna Jaya

\begin{tabular}{|c|c|c|}
\hline $\begin{array}{c}\text { Pengakuan Pendapatan menurut } \\
\text { SAK ETAP }\end{array}$ & $\begin{array}{c}\text { Pengakuan Pendapatan menurut } \\
\text { Perusahaan }\end{array}$ & $\begin{array}{c}\text { Kesesuaian } \\
\text { dengan SAK } \\
\text { ETAP }\end{array}$ \\
\hline $\begin{array}{c}\text { Entitas telah mengalihkan risiko } \\
\text { dan manfaat yang signifikan dari } \\
\text { kepemilikan barang kepada } \\
\text { pembeli. }\end{array}$ & $\begin{array}{c}\text { Perusahaan telah mengalihkan risiko } \\
\text { dan manfaat atas barang dagangan } \\
\text { kepada konsumen saat transaksi terjadi. }\end{array}$ & Sesuai \\
\hline $\begin{array}{c}\text { Entitas tidak mempertahankan atau } \\
\text { meneruskan baik keterlibatan } \\
\text { manajerial sampai kepada tingkat } \\
\text { di mana biasanya diasosiasikan } \\
\text { dengan kepemilikan maupun } \\
\text { kontrol efektif atas barang yang } \\
\text { terjual. }\end{array}$ & $\begin{array}{c}\text { Setelah terjadi transaksi dengan } \\
\text { konsumen, perusahaan tidak lagi } \\
\text { mempertahankan dan mengontrl barang } \\
\text { dagangan yang terjual. }\end{array}$ & Sesuai \\
\hline $\begin{array}{c}\text { Jumlah pendapatan dapat diukur } \\
\text { secara andal. }\end{array}$ & $\begin{array}{c}\text { Pendapatan yang diakui oleh } \\
\text { perusahaan merupakan harga dari hasil } \\
\text { kesepakatan oleh kedua pihak dan } \\
\text { tersimpan dalam sistem komputer. }\end{array}$ & Sesuai \\
\hline $\begin{array}{c}\text { Distribusi penjualan perusahaan } \\
\text { memberikan kontribusi besar bagi } \\
\text { ekonomi yang berhubungan } \\
\text { dengan transaksi akan mengalir } \\
\text { masuk ke dalam entitas. }\end{array}$ & $\begin{array}{c}\text { pedagang kecil dan konnsumen serta } \\
\text { perusahaan akan menerima imbalan kas } \\
\text { dari penjualan tersebut. }\end{array}$ & Sesuai \\
\hline $\begin{array}{c}\text { Biaya yang telah atau akan terjadi } \\
\text { sehubungan dengan transaksi dapat } \\
\text { diukur secara andal. }\end{array}$ & $\begin{array}{c}\text { Biaya yang terjadi atas penjualan } \\
\text { barang dapat diukur dengan andal dan } \\
\text { diakui sebagaimana mestinya dan } \\
\text { dilaporkan dengan andal. }\end{array}$ & Sesuai \\
\hline
\end{tabular}

Sumber : Data yang diolah 
Tabel 4.3 Perbandingan Kriteria Pengukuran Pendapatan Menurut SAK ETAP dengan PT. Metta Karuna Jaya

\begin{tabular}{|c|c|c|}
\hline $\begin{array}{l}\text { Pengukuran Pendapatan } \\
\text { menurut SAK ETAP }\end{array}$ & Pengukuran Pendapatan Perusahaan & $\begin{array}{c}\text { Kesesuaian } \\
\text { dengan SAK } \\
\text { ETAP }\end{array}$ \\
\hline $\begin{array}{l}\text { Entitas harus mengukur } \\
\text { pendapatan berdasarkan nilai wajar } \\
\text { atas pembayaran yang diterima } \\
\text { atau masih harus diterima. }\end{array}$ & $\begin{array}{l}\text { Harga yang diberikan oleh perusahaan } \\
\text { atas setiap penjualan yang dilakukan } \\
\text { perusahaan merupakan ketentuan yang } \\
\text { diberlakukan pihak perusahaan dengan } \\
\text { harga yang berlaku saat ini, dan juga } \\
\text { disepakati oleh kedua belah pihak yang } \\
\text { melakukan transaksi. }\end{array}$ & Sesuai \\
\hline $\begin{array}{l}\text { Entitas harus memasukkan dalam } \\
\text { pendapatan manfaat ekonomi yang } \\
\text { diterima atau masih harus diterima } \\
\text { secara bruto. } \\
\end{array}$ & $\begin{array}{c}\text { Dalam penyajian laporan keuangan } \\
\text { (neraca) perusahaan memasukkan } \\
\text { pandapatan dari manfaat ekonomi yang } \\
\text { diterima atau masih harus diterima. }\end{array}$ & Sesuai \\
\hline $\begin{array}{l}\text { Entitas harus mengeluarkan dari } \\
\text { pendapatan sejumlah nilai yang } \\
\text { menjadi bagian pihak ketiga } \\
\text { seperti pajak penjualan, pajak atas } \\
\text { barang dan jasa, dan pajak } \\
\text { pertambahan nilai. }\end{array}$ & $\begin{array}{c}\text { Perusahaan merupakan wajib pajak } \\
\text { yang selalu membayarkan pajaknya } \\
\text { secara rutin. }\end{array}$ & Sesuai \\
\hline
\end{tabular}

Sumber : Data yang diolah

Tabel 4.4 Perbandingan Kriteria Pengungkapan Pendapatan Menurut SAK ETAP dengan PT. Metta Karuna Jaya

\begin{tabular}{|c|c|c|}
\hline $\begin{array}{c}\text { Pengungkapan Pendapatan } \\
\text { menurut SAK ETAP }\end{array}$ & $\begin{array}{c}\text { Pengungkapan Pendapatan menurut } \\
\text { Perusahaan }\end{array}$ & $\begin{array}{c}\text { Kesesuaian } \\
\text { dengan SAK } \\
\text { ETAP }\end{array}$ \\
\hline $\begin{array}{c}\text { Kebijakan akuntansi yang } \\
\text { diterapkan sebagai dasar } \\
\text { pengakuan pendapatan, termasuk } \\
\text { metode yang diterapkan untuk } \\
\text { menentukan tingkat penyelesaian } \\
\text { transaksi yang melibatkan } \\
\text { penyediaan jasa. }\end{array}$ & $\begin{array}{c}\text { Kebijakan akuntansi yang diterapkan } \\
\text { oleh perusahaan sebagai dasar } \\
\text { pengakuan pendapatan menggunakan } \\
\text { metode accrual basic dalam } \\
\text { menentukan tingkat penyelesaian } \\
\text { transaksi. }\end{array}$ & Sesuai \\
\hline $\begin{array}{c}\text { Jumlah setiap kategori pendapatan } \\
\text { yang diakui selama periode, } \\
\text { termasuk pendapatan yang timbul } \\
\text { dari penjualan barang, penyediaan } \\
\text { jasa, bunga, royalti, dividen, dan } \\
\text { jenis pendapatan signifikan } \\
\text { lainnya. }\end{array}$ & $\begin{array}{c}\text { Jumlah setiap kategori pendapatan yang } \\
\text { diakui selama periode disajikan dalam } \\
\text { laporan keuangan perusahan secara } \\
\text { benar. }\end{array}$ & Sesuai \\
\hline
\end{tabular}

Sumber : Data yang diolah 


\section{KESIMPULAN DAN SARAN}

\subsection{Kesimpulan}

Berdasarkan penelitian yang dilakukan pada PT. Metta Karuna Jaya dapat diberikan kesimpulan sebagai berikut:

1. Sumber utama pendapatan PT. Metta Karuna Jaya berasal dari penjualan barang dagang, yaitu produk-produk minuman dari susu yang dijual kembali kepada konsumen atau pengecer.

2. PT. Metta Karuna Jaya telah memahami dan menerapkan konsep pengakuan, pengukuran, dan pengungkapan pendapatan berdasarkan SAK ETAP dengan baik.

3. Metode pengakuan pendapatan PT. Metta Karuna Jaya berdasarkan metode accrual basic, yaitu pendapatan diakui saat terjadinya transaksi penjualan.

4. Pendapatan PT. Metta Karuna Jaya diukur berdasarkan jumlah penghasilan yang berasal dari penjualan produk perusahaan serta dilihat dari setoran kas oleh pembeli berupa faktur penjualan yang mencantumkan tanggal jatuh tempoh pembayaran sesuai dengan produk yang dibeli pelanggan.

5. PT. Metta Karuna Jaya mengungkapkan pendapatannya dalam laporan laba rugi tahunan perusahaan, ditempatkan pada posnya masing-masing sesuai dengan kategori pendapatan dan beban perusahaan.

\subsection{Saran}

Berikut adalah saran-saran yang penulis berikan :

1. Kinerja perusahaan kiranya semakin ditingkatkan kualitasnya baik dalam memberikan pelayanan bagi konsumen melalui penjualan produknya sehingga dalam bisnis perusahaan semakin berkembang lagi.

2. Kebijakan akuntansi yang diterapkan oleh perusahaan perlu dipertahankan sesuai dengan kebijakan akuntansi keuangan yang berlaku.

3. Laporan keuangan yang disajikan dapat lebih akurat dan memberikan estimasi bagi masa depan perusahaan agar PT. Metta Karuna Jaya bisa menjadi perusahaan yang semakin berkembang juga dapat go public.

\section{DAFTAR PUSTAKA}

Arsani, Kadek, 2013. Perlakuan Akuntansi Pendapatan dan Beban Berbasis SAK ETAP dan Implikasinya pada Laporan Keuangan KSP Duta Sejahtera. Jurnal Juni 2013, Volume 3 Nomor $3 . \quad$ Universitas Udayana. Bali. ojs.unud.ac.id/index.php/Akuntansi/article/view5663. Diakses Maret, 28, 2016.

Hery., 2013, Akuntansi Keuangan Menengah, Edisi Pertama, Center of Academic Publishing Service. Jakarta.

Ikatan Akuntan Indonesia., 2013, Entitas Tanpa Akuntabilitas Publik. Dewan Standar Akuntasi Keuangan. Jakarta.

Marcella, Synthia, 2014. Analisis Pengakuan dan Pengukuran Pendapatan Berdasarkan PSAK No. 23 pada PT. Pandu Siwi Sentosa Palembang. Sekolah Tinggi Ilmu Ekonomi Multi Data Palembang. Palembang. eprints.mdp.ac.id/1160/. Diakses Maret, 28, 2016.

Pawan, Elisabeth, 2013. Pengakuan, Pengukuran, Pengungkapan, \& Pelaporan Pendapatan Berdasarkan PSAK No. 23 Pada PT. Pegadaian (Persero). Jurnal Juni 2013, Volume 1
Nomor
3. Universitas
Sam
Ratulangi.
Manado.

ejournal.unsrat.ac.id/index.php/emba/article/view/1653. Diakses April, 5, 2015.

Pontoh, Winston, 2013. Akuntansi Konsep dan Aplikasi. Halaman Moeka. Jakarta.

Sujarweni, Wiratna, 2014. Metodologi Penelitian. Pustaka Baru Press. Yogyakarta.

Sugiyono, 2014. Metode Penelitian Bisnis. Alfabeta. Bandung. 
Tanugraha, Jevon, 2012. Evaluasi Penerapan Standar Akuntansi Keuangan Entitas Tanpa Akuntansi Publik pada PT. TDMN. Jurnal Mei 2012, Volume 1 Nomor 3. Unika Widya Mandala. Surabaya. journal.wima.ac.id/index.php/BIMA/article/view/120. Diakses September, 25, 2017.

Vasiliauskaite, Asta, 2013. European Property Taxation: New Sources Of Revenue, Cases Of The EU Countries. Jurnal Oktober 2013, Volume 18 Nomor 3. Kaunas University of Technology. Lithuania. ecoman.ktu.lt/index.php/Ekv/article/view/4187. Diakses September, 25, 2017.

Wahdatana, Anis, 2016. Analisis Pengakuan Pendapatan dan Beban pada PT Duta Satrya Adhi Persada Banjarbaru. Jurnal November 2016, Volume 2 Nomor 3. Sekolah Tinggi Ilmu Ekonomi Pancasetia Banjarmasin. Banjarmasin. sia.stiepancasetia.ac.id/download-jurnal.php?id=168. Diakses Desember, 11, 2017. 